\title{
A proposed solution to the species problem in velvet worm conservation (Onychophora)
}

\author{
Ángel Sosa-Bartuano', Julián Monge-Nájera² \& Bernal Morera-Brenes ${ }^{3}$ \\ 1. Colección Zoológica Dr. Eustorgio Méndez, Departamento de Investigación en Entomología Médica, Instituto Conmemorativo Gorgas de \\ Estudios de la Salud (ICGES), Ciudad de Panamá, Panamá; asosa2983@gmail.com \\ 2. Laboratorio de Ecología Urbana, Universidad Estatal a Distancia (UNED), 2050 San José, Costa Rica; julianmonge@gmail.com \\ 3. Laboratorio de Sistemática, Genética y Evolución (LabSGE), Escuela de Ciencias Biológicas, Universidad Nacional, Heredia, Costa Rica; \\ bernalmorera@gmail.com
}

Received 31-VIII-2017 • Corrected 01-XI-2017 • Accepted 21-XI-2017

\begin{abstract}
Onychophorans or velvet worms are the only phylum without extant marine species and the only invertebrates with a true placenta, but most species are rare and thus more likely to become extinct. A key obstacle for their conservation is the time and work needed to describe species with the high standards of current taxonomy, and many species will remain undescribed and without any name for years. Here we propose a way to associate information with undescribed species: "common names", a solution that has proved its value in ornithology. Onychophoran common names must include a geographic indicator and a description of a salient characteristic, and to show its viability, here we apply our proposal to the velvet worm fauna of southeastern Central America. Common names like "Lajas Ferruginous Brown Onychophoran", "Churuquita Collared Cinnamon Rufous Onychophoran" and "Antón Collared Mauve Onychophoran" will help conservation until formal Latin binomials become available.
\end{abstract}

Key words: Conservation Onychophora, new solutions for threatened biodiversity, non-technical names for invertebrates, informal names, velvet worm common names
RESUMEN: Propuesta de una solución al problema de definir especies en la conservación de gusanos de terciopelo (Onychophora). Los onicóforos o gusanos de terciopelo son el único filo sin especies marinas vivas y los únicos invertebrados con placenta verdadera, pero la mayoría son especies raras y por lo tanto, con mayores probabilidades de extinción. Un obstáculo clave para su conservación es el trabajo necesario para describir formalmente las especies con los altos estándares de la taxonomía actual, y muchas especies permanecen sin describir y sin nombre por años. Aquí proponemos una forma de asociar información con especies no descritas: los "nombres comunes", una solución que ha demostrado su valor en ornitología. Los nombres comunes de los onicóforos deben incluir un indicador geográfico y descripción de una característica sobresaliente. Para demostrar su viabilidad, aquí aplicamos nuestra propuesta a la fauna de gusanos de terciopelo del sudeste de América Central. Nombres comunes como"Lajas Ferruginous Brown Onychophoran", "Churuquita Collared Cinnamon Rufous Onychophoran" y "Antón Collared Mauve Onychophoran" ayudarán a su conservación hasta que estén disponibles los binomios formales en latín.

Palabras clave: Conservación de Onychophora, nuevas soluciones para biodiversidad amenazada, nombres populares para invertebrados, nombres comunes de gusanos de terciopelo
Onychophorans have been called "living fossils" because they look externally like some of their Cambrian ancestors. They are the only phylum without extant marine species, the only invertebrates with a true placenta, and all species produce a nearly "instantaneous" net to capture prey (Monge-Nájera, 1995; Concha et al., 2015).

Unfortunately, most species are rare and thus more likely to become extinct, but their biodiversity is so poorly known that even in Costa Rica, where they have been studied for over 100 years, 18 undescribed species were recently reported (Barquero-González, Acosta-Chaves, Sotela, Brenes \& Morera-Brenes, 2016a). They are hard to find because, additionally to their small populations, they have a cryptic lifestyle, and we do not know exactly how many species exist, where they are, or what is their population status (Monge-Nájera, 1995; Barclay, Ash \& Rowell, 2000),

A key obstacle to the conservation of velvet worms is the large amount of funds, time and work needed to describe a single species with the high standards of current taxonomy, i.e. DNA sequencing, ultrastructural microscopy and statistical analyses of variation. As a result of these requirements, many species will remain undescribed for years. Without a name, any information useful for their 
conservation cannot be associated with particular species, leaving them in the dire situation that all organisms suffered before the work of Linnaeus (Blunt, 2002).

When obtaining specimens to describe new species is impractical, Marshall and Evenhuis (2015) recommend a norm in the International Code of Zoological Nomenclature that accepts an image as holotype. The image must be complete and adequate to make the species unequivocally recognizable. They applied this reasoning to describe the beefly Marleyimyia xylocopae on the basis a photograph, because the animal flew away and it is not probable that new specimens will be captured in a foreseeable future (Marshall \& Evenhuis, 2015).

The arguments of Marshall and Evenhuis (2015) apply to onychophorans because, in most cases, specimens are difficult to obtain and species could be identified unequivocally from photographs (Barquero-González et al., 2016a; 2016b). Frequently, only one species has a particular color pattern in a particular place, and species ranges are small (de Sena Oliveira, Read \& Mayer 2012; Barquero-González, et al., 2016a; 2016b): in other words, if you know the color pattern and locality, you know the species. There are exceptions: cryptic species that look similar but are genetically different taxa (Daniels, Picker, Cowlin \& Hamer, 2009), but there is currently no reason to believe that this a frequent case (for a review of species and their problems see de Sena Oliveira et al., 2012), and from the point of view of conservation, which is the point of view of our proposal, having a name that allows protection is better than having no name at all, even for cryptic species.

From a practical point of view, associating names to onychophoran populations is urgent to organize any information collected about them and to assess their conservation needs; and we propose a practical solution taken from ornithology by the second author.

Decades ago, the need for amateurs to identify birds led to the use of "common names", for example, "Atlantic Yellow-nosed Albatross" for Thalassarche chlororhynchos and "Sri Lanka Thrush" for Zoothera imbricata. For over a century, these common names have permitted the collection of millions of valuable records (e.g. the Christmas Bird Census that began in 1900: audubon. org). Ornithology may be the field where more amateurs make a significant contribution to science with their observation of behaviors, distribution and population status, in what is now known as "citizen science" (Sullivan, Wood, lliff, Bonney, Fink \& Kelling, 2009).

Here we propose their use, in the field of "Onychophorology", for all species that lack formal descriptions. Common names could also be coined for species with Latin names, to facilitate citizen science projects. The names must include a geographic indicator and a salient characteristic (usually coloration), and should be backed up by an appropriate photograph for critical review. Of course, if formal descriptions later become available, the common name should be mentioned so that any previous information based on the common name can be carefully associated with the now properly named species.

As an example, we apply our proposal to the velvet worm fauna of southern Central America, which has been studied since the 19th century thanks to the National Museum in Costa Rica and biodiversity research associated with the construction the Panama Canal. For a summary of current knowledge about Central American Onychophorans see Digital Appendix 1. We also present new photographic evidence for the existence of 13 undescribed species from Panama, two from Nicaragua and one from Costa Rica; and provide common names for all of them, as well as for 16 undescribed Costa Rican species previously published by Barquero-González et al. (2016a).

\section{MATERIALS AND METHODS}

We collected all the photographs and videos onychophorans from Nicaragua, Costa Rica and Panama publically available online using the search terms "onychophora", "velvet worm", "onicóforo", "gusano de terciopelo", "peripatus", and "peripato", in conjunction with each country name, with the search motor Google.com (August $5^{\text {th }}, 2017$ ); and also named the species presented by Barquero-González et al. (2016a; 2016b). Colors for Panamanian species are based on Köhler (2012).

\section{RESULTS}

The names for undescribed species are presented for Panama, Costa Rica and Nicaragua. Ecologically, the distribution of these undescribed onychophorans from Panama includes both seasonal habitats and evergreen habitats, and from a varietyof altitudes above sea level. Geographically, they cover from Isla Colón and Las Lajas in western Panama to Cerro Pirre in the east, and from Barro Colorado Island in the north to Río Playita in the south; most records are from Central Panama, closer to the headquarters of scientific institutions (Digital Appendix 1, and Figure 1 in Digital Appendix 2). Costa Rican records include mid-altitude volcanic areas and lowland forest. The two Nicaraguan specimens are from rainforest. 
Panama: We name the undescribed Panamanian species as follows (Figure 2 in Digital Appendix 2; details in Digital Appendix 3):

- Drago Light Clay Onychophoran

- Lajas Ferruginous Brown Onychophoran

- Churuquita Collared Cinnamon Rufous Onychophoran

- Churuquita Cinnamon Rufous Onychophoran

- Antón Collared Mauve Onychophoran

- Guabo Mauve Onychophoran

- Pirre Golden Onychophoran

- Chorrera Collared Purple Onychophoran

- Sajalices Collared Mauve Onychophoran

- Colorado Dark Mauve Onychophoran

- Cocobolo Mauve Cinnamon Onychophoran

- Torrijos Drab Brown Onychophoran

- Playita Light Vinaceous Onychophoran

Costa Rica: We name the Costa Rican species (figures 1, 2, 3 in Barquero-González et al., 2016a) as follows:

- Piro Orange Ruby Onychophoran

- Agujas Plum Blue Onychophoran

- Agujas Purple Brown Onychophoran

- Agujas Plum Blue Onychophoran (same species as number 2)

- Corcovado Cinnamon Onychophoran

- Osa Burgundy Onychophoran

- Manzanillo Gray Burgundy Onychophoran

- Guayacán Rusty Brown Onychophoran

- Limón Pink Brown Onychophoran

- Pejibaye Mauve Onychophoran

- Quesada Burgundy Brown Onychophoran

- Cahuita Salmon Onychophoran

- Tausito Light Orange Onychophoran

- Volio Light Raspberry Onychophoran

- Gandoca Blue Onychophoran

- Sarapiquí Yellow Brown Onychophoran

- Tapantí Red Onychophoran

- Guayacán Rusty Brown Onychophoran (same species as number 8 )
Additionally, we name the species photographed by Frank González in Biolley, Buenos Aires, Puntarenas, Costa Rica (24 July 2017; Figure 3 in Digital Appendix 2):

- Biolley Collared Raspberry Onychophoran

Nicaragua: We name the species photographed by Aurelio Núñez in Amak (14⒈ $\left.14^{\prime} 20.74^{\prime \prime} \mathrm{N}, 85^{\circ} 9^{\prime} 7.02^{\prime \prime \prime} \mathrm{W}\right)$, Reserva de la Biosfera Bosawas, Jinotega, northern Nicaragua (2 November 2015; Figure 4 in Digital Appendix 2):

- Amak Nicaragua Sandy Brown Onychophoran

And the species photographed by Javier Canteros, El Castillo, southern Nicaragua (2016; Figure 5 in Digital Appendix 2):

- Castillo Vinous Onychophoran

\section{DISCUSSION}

Onychophoran populations have survived five mass extinctions, large fires and even devastating volcanic eruptions (Monge-Nájera \& Hou, 2000), as well as habitat urbanization, leading to the existence urban populations (Barquero-González et al., 2016b; Barrett, Recio, Barratt, Seddon \& van Heezik, 2016; Monge-Nájera, 2018). Nevertheless, they can become extinct: all oceanic species, as well as those from North America, Europe and China have disappeared: extant onychophorans need to be included in conservation initiatives (e.g. New, 1995; Fox, 2014).

Obstacles for the conservation of velvet worms are political and practical. Authorities in charge of conservation consider economic and political costs. Here, onychophorans, like other worms, have a disadvantage when compared with charismatic species like the panda, and it is difficult to obtain funds for their study and conservation (Monge-Nájera, 2017).

Beyond reasons of public image, the main practical obstacle in onychophoran conservation is the tremendous worldwide lag in the identification, description and naming of species (de Sena Oliveira et al., 2012). All species need names to associate them with information that can be used in their conservation. These names do not necessarily have to be formal Linnaean binomials, and in the case of onychophorans, each locality usually has its own species (Monge-Nájera, 1995; Monge-Nájera \& Lourenco, 1995; de Sena Oliveira et al., 2012). 
Our results, here applied -as an example- to all the unnamed species from southeastern Central America that we could find, show how species can be given names without waiting for expensive and labor-intensive formal descriptions. Naming them is a key first step to collect and organize information about their ecology, evolution, and conservation, among others (Blunt, 2002). Any errors that may be caused by cryptic species are small in comparison with the gain of protecting these extraordinary animals. Unlike poorly elaborated formal descriptions that too frequently complicate onychophoran taxonomy (de Sena Oliveira et al., 2012), common names will not burden the scientific nomenclature with invalid scientific names because they are not scientific names themselves, and will not interfere if formal descriptions are later published.

We hope that modern technology will allow amateurs and professionals to share information, recognize species in the field, discover new species, and record all kinds of data for the conservation of this old and extraordinary phylum.

\section{ACKNOWLEDGMENTS}

We thank Zaidett Barrientos, Frank González, Aurelio Núñez and Carolina Seas for information, photographs and assistance; Pedro Castillo, Konrad Mebert, Renato Morales, Rodolfo Martínez, Héctor Vega, Eileen Rivera, Nhu Nguyen, Twan Leenders, Loes Groenendijk and Kees Groenendijk for allowing us to use photographs, and Laurencio Martínez, Karla Ramos, César Barrio Amorós and Claudia Koch for support in the field.

\section{REFERENCES}

Barclay, S., Ash, J. E., \& Rowell, D. M. (2000). Environmental factors influencing the presence and abundance a log-dwelling invertebrate, Euperipatoides rowelli (Onychophora: Peripatopsidae). Journal Zoology, 250(4), 425-436.doi:10.1111/j.1469-7998.2000.tb00786.x

Barquero-González, J.P., Acosta-Chaves, V. J., Sotela, M. L., Brenes, F. V., \& Morera-Brenes, B. (2016a). Evidencia fotográfica de especies desconocidas de onicóforos (Onychophora: Peripatidae) de Costa Rica. UNED Research Journal, 8(2), 139-147.doi:10.22458/urj.v8i2.1553

Barquero-González, J. P., Cabrera Alvarado, A. A., Valle-Cubero, S., Monge-Nájera, J., \& Morera-Brenes, B. (2016b). The geographic distribution Costa Rican velvet worms (Onychophora: Peripatidae). Revista de Biología Tropical, 64(4), 1401-1414.doi:10.15517/rbt.v64i4.19486
Barrett, D., Recio, M. R., Barratt, B. I., Seddon, P. J., \& van Heezik, Y. (2016). Resource selection by an ancient taxon (Onychophora) in a modern urban landscape: A multi-scale analysis approach to assist in the conservation an animal phylum. Landscape and Urban Planning, 148, 27-36.

Blunt, W. (2002). Linnaeus: The Compleat Naturalist. Princeton: Princeton University Press.

Concha, A., Mellado, P., Morera-Brenes, B., Sampaio-Costa, C., Mahadevan, L., \& Monge-Nájera, J. (2015). Oscillation the velvet worm slime jet by passive hydrodynamic instability. Nature Communications, 6, 6292. doi: 10.1038/ ncomms7292

Costa, C. S. (2016). Systematic and phylogenetic analysis Epiperipatus Clark, 1913 based on molecular and morphological data (Onychophora, Peripatidae). Ph.D. Thesis, Instituto de Biociências (IB). Universidade de São Paulo (USP). São Paulo, SP, Brazil.

Daniels, S. R., Picker, M. D., Cowlin, R. M., \& Hamer, M. L. (2009). Unravelling evolutionary lineages among South African velvet worms (Onychophora: Peripatopsis) provides evidence for widespread cryptic speciation. Biological Journal of the Linnean Society, 97(1), 200-216.

de Sena Oliveira, I., Read, V. M. S. J., \& Mayer, G. (2012). A world checklist Onychophora (velvet worms), with notes on nomenclature and status names. ZooKeys, 211, 1.doi: 10.3897/zookeys.211.3463

Fox, R. (2014, August 4th). Booklet on peripatus worm released. Otago Daily Times, South Island, New Zealand.

Köhler, G. (2012). Color Catalogue for Field Biologist. Offenbach, Germany: Herpeton Verlag.

Marshall, S. A., \& Evenhuis, N. L. (2015). New species without dead bodies: a case for photo-based descriptions, illustrated by a striking new species Marleyimyia Hesse (Diptera, Bombyliidae) from South Africa. ZooKeys, 525, 117.doi:10.3897/zookeys.525.6143

Monge-Nájera, J. (1995). Phylogeny, biogeography and reproductive trends in the Onychophora. Zoological Journal the Linnean Society, 114, 21-60.

Monge-Nájera, J. (2017). The power short lectures to improve support for biodiversity conservation unpopular organisms: an experiment with worms. UNED Research Journal, 9(1), 145-150.

Monge-Nájera, J. (2018). City Worms: why do fragile invertebrates from an ancient lineage live in heavily urbanized areas? UNED Research Journal, 10(1), in press.

Monge-Nájera, J., \& Lourenço, W. R. (1995). Biogeographic implications evolutionary trends in onychophorans and scorpions. Biogeographica-Paris, 71, 179-186. doi:10.1111/j.1096-3642.1995.tb00111.x 
Monge-Nájera, J., \& Hou, X. (2000). Disparity, decimation and the Cambrian" explosion": comparison early Cambrian and Present faunal communities with emphasis on velvet worms (Onychophora). Revista de Biología Tropical, 48(2-3), 333-351.

Monge-Nájera, J., \& Hou, X. (2002). Experimental taphonomy velvet worms (Onychophora) and implications for the Cambrian" explosion, disparity and decimation" model. Revista de Biología Tropical, 50(3-4), 1133-1138.

Monge-Nájera, J., \& Morera-Brenes, B. (2016). Velvet worms (Onychophora) in folklore and art: geographic pattern, types cultural reference and public perception. British Journal Education, Society \& Behavioural Science, 10(3), 1-9doi:10.9734/BJESBS/2015/18945

Morera-Brenes, B. (2012). Los onicóforos, fósiles caminantes. El Salvador Ciencia \& Tecnología, 17(23), 8-13.

New, T. R. (1995). Onychophora in invertebrate conservation: priorities, practice and prospects.
Zoological Journal the Linnean Society,114(1), 77-89. doi:10.1111/j.1096-3642.1995.tb00113.x

Peck, S. B. (1975). A review the New World Onychophora, with the description a new cavernicolous genus and species from Jamaica. Psyche, 82(3-4), 341-358. doi:10.1155/1975/98614

Read, V. S. J. (1988). The application scanning electron microscopy to the systematics the neotropical Peripatidae (Onychophora). Zoological Journal the Linnean Society, 93(3), 187-223.doi:10.1111/j.1096-3642.1988.tb01361.x

Sampaio-Costa, C., Chagas-Junior, A., \& Baptista, R. L. (2009). Brazilian species Onychophora with notes on their taxonomy and distribution. Zoologia (Curitiba), 26(3), 553561.doi:10.1590/S1984-46702009005000004

Sullivan, Wood, Iliff, Bonney, Fink \& Kelling 2009 eBird: a citizen-based bird observation network in the biological sciences. Biological Conservation, 142, 10, 2282-2292.

\section{EDITED BY CAROLINA SEAS}

See Digital Appendix at: / Ver Apéndice digital en: http://investiga.uned.ac.cr/revistas/index.php/cuadernos 